\title{
MENINGKATKAN KEMAMPUAN APLIKASI LOGIKA MATEMATIKA MELALUI PENDEKATAN REALISTIK DI SMAN 19 BEKASI
}

\author{
Rifki Ristiawan \\ Program Studi Informatika, Universitas Indraprasta PGRI \\ Email: rifki2889@gmail.com
}

\begin{abstract}
Abstrak
Kemampuan aplikasi siswa merupakan hal yang harus ditingkatkan dalam pembelajaran matematika. Seringkali kelemahan dalam pendidikan matematika adalah kurangnya keterkaitan beberapa materi ajar matematika di sekolah dengan kehidupan sehari-hari siswa seperti logika matematika. Situasi tersebut mendorong dikembangkan pemikiran bahwa pembelajaran matematika sebaiknya bersifat kontekstual. Salah satu alternatif yang diperkirakan mampu meningkatkan kemampuan aplikasi siswa, yaitu menggunakan pendekatan pembelajaran realistik. Penelitian ini merupakan penelitian tindakan kelas pada siswa kelas X.1 SMAN 19 Kab.Bekasi pada tahun ajaran 2012/2013 dengan jumlah siswa sebanyak 20. Hasil yang diperoleh adalah: (a) aktivitas siswa mengalami peningkatan pada tiap siklusnya, presentase aktivitas siswa paling tingi terdapat pada siklus 3 yaitu sebesar $85,26 \%$. Sedangkan aktivitas guru selama proses pembelajaran selalu berpijak pada tahap-tahap pembelajaran yang telah direncanakan. (b) kemampuan aplikasi siswa sebelum diterapkan pendekatan pembelajaran realistik sebesar 31,85\% menunjukkan pada kriteria sangat rendah. (c) Rata-rata kemampuan aplikasi logika siswa pada siklus 1 sebesar 65,42\% dengan kriteria cukup, siklus 2 sebesar 70,6\% dengan kriteria cukup, dan siklus 3 sebesar 76,10\% dengan kriteria tinggi. (c) kemampuan aplikasi siswa setelah diterapkan pendekatan pembelajaran realistik menunjukkan pada kriteria tinggi yaitu 75,85\% dan mengalami peningkatan 44\% dari kemampuan aplikasi siswa sebelum pembelajaran.
\end{abstract}

Kata Kunci : Aplikasi Logika, Matematika Realistik

\begin{abstract}
Student's application skill is something that must be improved in learning mathematics. The lack of relevance of some mathematics teaching materials such as mathematical logic in schools with daily life of students often creates a weakness in mathematics education. This situation encourages an idea that mathematics learning should be contextual. One of alternatives estimated to be able to improve student's application skill is a realistic learning approach. This research is a classroom action research on the 20 students of class X.1 in SMAN 19 of academic year 2012/2013 in Bekasi regency. The results obtained are: (a) students' activities have increased in each cycle, with the highest percentage of activity in cycle 3 of $85.26 \%$. While the teacher's activities during the learning process are always based on the planned learning stages. (b) students' application skill before applying realistic learning approach is $31.85 \%$, indicating a very low criterion. (c) The average student's logic application skill in cycle 1 is $65.42 \%$ with enough criterion, cycle 2 is 70,6\% with enough criterion, and cycle 3 is 76,10\% with high criterion. (c) students' application skill after applying realistic learning approach shows a high criterion of $75.85 \%$ and experiences $44 \%$ increase from student's application before before learning.
\end{abstract}

Keywords: Logic Application, Realistic Mathematics

\section{PENDAHULUAN}

Dalam pelaksanaan pembelajaran matematika di sekolah diharapkan agar para siswa diberi pengetahuan mengenai adanya hubungan antara matematika dengan kehidupan atau berbagai ilmu lain. Dan sebagai tindak lanjutnya, sangat diharapkan agar para siswa diberikan penjelasan pula dengan melihat berbagai contoh penggunaan matematika sebagai alat untuk memecahkan masalah dalam kehidupan.

Menurut Romberg [1], dalam pendidikan khususnya pendidikan matematika, individu 
atau kelompok dapat membuat suatu inovasi untuk memperbaiki suatu pembelajaran, produk ini mungkin berupa produk materi pembelajaran baru, teknik pembelajaran baru, ataupun program pembelajaran baru. Bentuk inovasi tersebut bertujuan untuk mengoptimalkan hasil proses belajar mengajar, yang ditandai dengan meningkatnya kemampuan siswa dalam menyerap konsep, algoritma matematika, dan kemampuan aplikasi konsep siswa dalam menyelesaikan masalah kehidupan sehari-hari.

Jika kita pertimbangkan kembali materi matematika di sekolah, maka akan cukup jelas terbukti bahwa sudah ada materi dalam pelajaran matematika di sekolah yang mengarahkan siswa dan pengajar untuk berpikir logis sebagai bekal untuk membantu menyelesaikan masalah, karena memang pada dasarnya logika adalah ilmu yang mempelajari asas-asas penalaran yang benar dan tertuang dalam logika matematika. Kemampuan aplikasi kosep logika matematika merupakan hal yang perlu dikembangkan, karena dari kemampuan inilah siswa akan mengembangkan kemampuan berpikir tingkat tinggi sedemikian sehingga akan mempermudah siwa dalam mempelajari materi pelajaran matematika yang lain

Seringkali kelemahan yang terjadi dalam pendidikan matematika adalah kurangnya keterkaitan antara pembelajaran matematika di sekolah dengan dunia nyata dan kehidupan sehari-hari siswa. Memang untuk beberapa cabang matematika tertentu, misalnya aritmetika, geometri, dan statistika kaitan antara cabang-cabang matematika tersebut dengan kehidupan sehari-hari cukup jelas. Tetapi, kebanyakan cabang atau topik matematika yang lain, keterkaitan itu tidak begitu tampak.

Dari hasil observasi dan refleksi yang telah dilakukan pada siswa kelas X.1 SMAN 19 Kab.Bekasi pada tahun ajaran 2012/2013 diketahui bahwa kemampuan siswa dalam mengerjakan soal-soal dalam ranah kognitif aplikasi dapat dikategorikan belum berhasil, karena hanya $9 \%$ siswa yang dapat mengerjakan soal aplikasi pada pokok bahasan logika matematika. Ini memberikan arti terdapat masalah baik dalam kemampuan siswa dalam menyerap pelajaran ataupun strategi pembelajaran yang diterapkan guru di dalam kelas masih belum optimal.

Inti dari pendekatan realistik adalah membangun proses pendidikan formal yang bersifat progresif. "Proses yang berawal dari sesuatu yang konkret ke abstrak". pendekatan realistik telah diadopsi dalam pendidikan literatur psikologi di Amerika Serikat untuk setidaknya satu abad terakhir. Urutan instruksional dalam pendekatan realistik dapat diartikan sebagai "garis pembelajaran" di mana konteks masalah digunakan sebagai titik awal untuk memperoleh penalaran informal siswa. Dalam tahapannya, guru memperkenalkan siswa strategi pra-formal dan model visual yang semakin lebih formal untuk mendukung pola berpikir matematis mereka. Strategi pra-formal seringkali lebih sederhana dan efisien. Model pra-formal adalah representasi yang bisa digunakan untuk memecahkan masalah di berbagai konteks, seperti tabel rasio atau garis bilangan ganda untuk menyelesaikan suatu proporsi. Strategi dan model pra-formal menawarkan tambahan manfaat menjadi lebih dekat dengan bagaimana seorang siswa dapat menemukan alasan terhadap terjadinya masalah. Terkadang tidak seefisien algoritma formal, strategi dan model pra-formal lebih baik dipahami. Treffers mendeskripsikan ini sebagai matematika "horizontal" dan "vertikal", di mana mateamtika horizontal adalah proses pengembangan matematika sebagai alat untuk memecahkan masalah dalam konteks yang realistis dan matematika vertikal pemprosesan lebih lanjut dari domain 
matematika yang di kembangkan pada tahapan horizontal [3].

Meskipun tak ada cara yang terbaik dalam pembelajaran ataupun cara belajar, sebagaimana yang dikatakan oleh Entwistle [1] 'There can be no 'right' way to study or 'best' way to teach...", yang berarti tidak ada cara belajar tunggal yang paling benar, dan cara mengajar yang paling baik, meskipun demikian, orang-orang berbeda dalam kemampuan intelektual, sikap, dan kepribadian sehingga mereka mengadopsi pendekatan pembelajaran yang karakteristiknya berbeda untuk belajar.

Salah satu upaya yang dapat dilakukan untuk meningkatkan kemampuan aplikasi konsep siswa adalah dengan menerapkan pendekatan realistik. Pembelajaran matematika realistik atau Realistic Mathematics Education (RME) yang dimaksudkan dalam hal ini adalah pembelajaran matematika sekolah yang dilakukan dengan menempatkan realitas dan pengalaman siswa sebagai titik awal pembelajaran[2].

Berdasarkan latar belakang masalah yang telah dikemukakan, masalah dalam penelitian ini dirumuskan sebagai berikut : (1) Bagaimana aktivitas siswa dan Guru pada setiap siklus selama memperoleh pembelajaran dengan pendekatan realistik? (2) Bagaimana kemampuan aplikasi konsep siswa pada setiap siklus selama memperoleh pembelajaran dengan pendekatan realistik? (3) Bagaimana kemampuan aplikasi konsep siswa setelah memperoleh pembelajaran dengan pendekatan realistik?

\section{METODE}

Penelitian dilakukan di kelas X.1 SMAN 19 Kab.Bekasi pada tahun ajaran 2012/2013 dengan jumlah siswa sebanyak 20 orang. Pemilihan lokasi ini berdasarkan permasalahan yang didapatkan di kelas X.1
SMAN 19 Kab. Bekasi mengenai rendahnya kemampuan aplikasi siswa pada konsep logika matematika. Penelitian tindakan kelas ini dilaksanakan dalam 3 siklus dengan dengan alokasi waktu tiap siklusnya adalah 3 kali pertemuan $(6 \times 45$ menit). Tiap siklus pembelajaran memiliki tahapan perencanaan (planning), pelaksanaan (acting), observasi (observing) dan refleksi (Reflection). Dalam penelitian ini, dilakukan pengamatan aktivitas guru dan siswa dalam proses pembelajaran dan menilai hasil belajar siswa yang diukur dengan nilai tes soal dalam ranah kognisi aplikasi. Tes dilakukan setiap akhir siklus dan observasi dilakukan dengan lembar observasi aktivitas siswa dan guru. Instrumen yang digunakan dalam penelitian ini telah teruji mulai dari indeks kesukaran, daya pembeda, reliabilitas dan validitasnya.

\section{HASIL DAN PEMBAHASAN}

Dalam kerangka pembelajaran matematika realistik, Freudenthal menyatakan bahwa "Mathematics is human activity", karenanya pembelajaran matematika disarankan berangkat dari aktivitas manusia. Pembelajaran matematika di sekolah hendaknya diarahkan pada perkembangan siswa meliputi kemampuan koneksi dan aplikasi sebagaimana dinyatakan dalam NCTM Standards [4], dimana dinyatakan bahwa pembelajaran matematika harus diarahkan pada pengembangan kemampuan berikut: (1) memperhatikan serta menggunakan koneksi matematik antar berbagai ide matematika, (2) memahami bagaimana ide-ide matematik saling terkait satu dengan yang lain sehingga terbangun pemahaman menyeluruh, dan (3) memperhatikan serta menggunakan matematika dalam konteks di luar matematika.

RME mencerminkan suatu pandangan tentang matematika sebagai sebuah subject matter, bagaimana anak belajar matematika, dan bagaimana matematika diajarkan. 
Pandangan ini terurai dalam enam karakteristik RME [7] : (1) Prinsip Aktivitas (2) Prinsip Realitas (3) Prinsip Tahap Pemahaman (4) Prinsip Intertwinement. (5) Prinsip Interaksi. (6) Prinsip Bimbingan.

Dari hasil observasi terhadap aktivitas siswa selama pembelajaran berlangsung dengan menerapkan pendekatan realistik pada tiap durasi 45 menit dengan parameter pengamatan meliputi: (1) konsentrasi siswa mengikuti kegiatan proses pembelajaran; (2) antusias siswa dalam mengerjakan lembar permasalahan; (3) keaktifan siswa dalam diskusi dengan pasangannya atau kelompoknya; dan (4) siswa berbagi ide dengan pasangannya maupun dengan teman sekelas.

Pada siklus I aktivitas siswa dalam pembelajaran logika matematika dengan pendekatan realistik masih belum mengalami peningkatan yang signifikan, dari hasil analisis lebar observasi aktivitas siswa, diketahui persentase aktivitas siswa mencapai 63,99\% dengan kriteria cukup baik. Begitu pula dengan aktivitas guru selama mengajar, diketahui berdasarkan analisis lembar observasi aktivitas guru persentase aktivitas guru mencapai 70,83\% dengan kategori baik. Temuan pada siklus I ini akan dijadikan acuan perbaikan pada siklus II.

Pada siklus II aktivitas siswa dalam pembelajaran logika matematika dengan pendekatan realistik sudah mengalami peningkatan dibandingkan dengan siklus I, dari hasil analisis lebar observasi aktivitas siswa, diketahui persentase aktivitas siswa mencapai $73,2 \%$ dengan kriteria baik. Berdasarkan analisis lembar observasi aktivitas guru, diketahui persentase aktivitas guru mengalami peningkatan dibanding siklus I dan telah mencapai $79,16 \%$ dengan kategori baik. Temuan pada siklus II ini akan dijadikan acuan perbaikan pada siklus III.

Pada siklus III aktivitas siswa dalam pembelajaran logika matematika dengan pendekatan realistik sudah mengalami peningkatan yang signifikan jika dibandingkan dengan dua siklus sebelumnya, dari hasil analisis lebar observasi aktivitas siswa, diketahui persentase aktivitas siswa mencapai 85,26\% dengan kriteria amat baik. Selain itu aktivitas guru juga mengalami peningkatan dari hasil analisis lembar observasi, dan diketahui aktivitas guru telah mencapai $87,5 \%$ dengan kategori amat baik. Hasil ini telah melampaui indikator keberhasilan penelitian yang telah ditetapkan sebelumnya. Sehingga penelitian ini dihentikan pada siklus III. Peningkatan aktivitas siswa dapat dilihat secara ringkas pada Gambar 1.

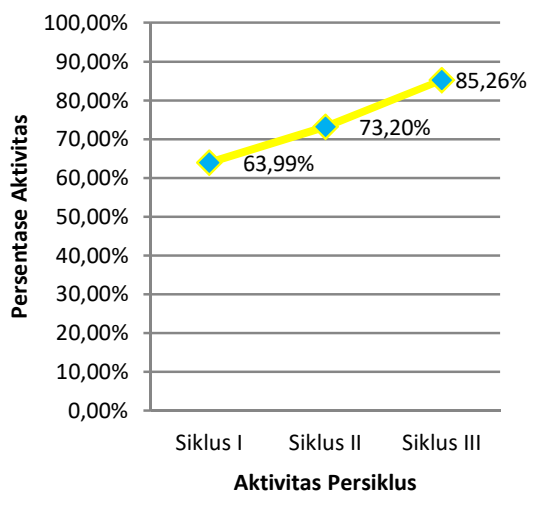

\section{Gambar 1. Peningkatan Aktivitas Siswa Tiap Siklus}

Adapun hasil analisis observer terhadap aktivitas guru dapat dilihat secara lebih spesifik pada Gambar 2. Aspek yang diobservasi untuk aktivitas guru selama pembelajaran ialah aktivitas apersepsi, pemberian motivasi terhadap siswa, bimbingan terhadap siswa yang mengalami kesulitan dalam proses pembelajaran yang dilakukan, pemberian umpan balik, interaksi dan responsi dengan siswa, dan pengelolaan kelas selama pembelajaran. 


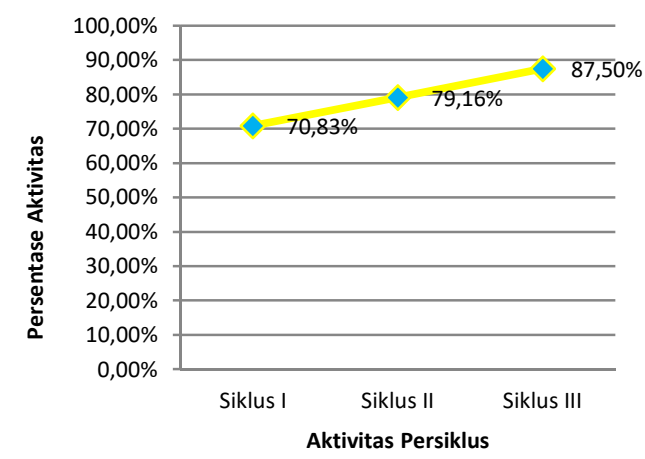

\section{Gambar 2. Peningkatan Aktivitas Guru Tiap Siklus}

Proses kognitif mengaplikasikan melibatkan pula penggunaan prosedurprosedur tertentu untuk mengerjakan soal latihan atau menyelesaikan masalah. Mengaplikasikan berkaitan erat dengan pengetahuan prosedural, menurut Anderson [5]."Pengetahuan prosedural adalah pengetahuan tentang cara melakukan sesuatu". Lebih lanjut Alexander [4], menyatakan bahwa Pengetahuan prosedural kerap kali berupa rangkaian langkah yang harus diikuti. Pengetahuan ini mencakup pengetahuan tentang keterampilan, algoritma, teknik, dan metode, yang semuanya disebut sebagai prosedur. Pengetahuan prosedural juga meliputi pengetahuan tentang kriteria yang digunakan untuk menentukan kapan harus menggunakan berbagai prosedur.

Lebih lanjut, Anderson [1] menyatakan bahwa "Kategori mengaplikasikan terdiri dari dua proses kognitif, yakni mengeksekusi dan mengimplementasikan. Suatu masalah aplikatif dikategorikan ke dalam mengeksekusi jika masalah tersebut adalah masalah yang familier atau tidak asing bagi siswa, dan dalam proses pemecahannya tidak memerlukan analisis yang mendalam. Dan proses implementasi mengharuskan siswa memahami masalahnya dan prosedur penyelesaiannya sampai tingkat tertentu. Dalam mengimplementasikan, memahami pengetahuan konseptual merupakan prasyarat untuk dapat mengaplikasikan pengetahuan prosedural.

Ketuntasan belajar yang dijadikan pijakan dalam penelitian ini berdasarkan petunjuk pengolahan penilaian Depdikbud [5] bahwa seseorang disebut telah tuntas belajar, jika sekurang-kurangnya dapat mengerjakan soal dengan benar sebanyak $65 \%$ dalam ulangan harian atau $60 \%$ dalam ulangan akhir. Secara proporsional, hasil belajar suatu rombongan belajar dikatakan baik apabila sekurang-kuranganya $85 \%$ anggotanya telah tuntas belajar. Apabila anggotanya yang tuntas hanya mencapai $75 \%$, maka hasil belajarnya dikatakan cukup. Hasil belajar dikatakan kurang apabila prosentase anggota yang tuntas kurang dari $60 \%$. Gambaran ketuntasan belajar siswa pada siklus I, siklus II dan siklus III pembelajaran ditampilkan pada Tabel 1 dan Gambar 3.

Pada siklus I telah terjadi peningkatan kemampuan aplikasi siswa, yaitu telah terdapat 3 orang siswa yang mencapai kategori tinggi, 14 siswa berkategori kemampuan cukup dan 2 siswa yang berkategori kemampuan rendah. Faktor utama dari peningkatan kemampuan aplikasi siswa pada siklus I adalah selain karena berkembangnya kemampuan aplikasi siswa pada konsep logika matematika yaitu siswa telah diajarkan bagaimana cara untuk menjawab masalah secara sistematis sesuai dengan rubrik skoring sehinga penilaian yang diperoleh tiap siswa menjadi lebih optimal.

Ketuntasan siswa pada siklus II adalah 85\% yaitu berkriteria tinggi, dengan rincian 17 orang telah tuntas dan 3 orang masih belum tuntas. Dari 17 dalam kategori tuntas, diketahui 16 diantaranya dalam kategori penilaian tinggi dan 1 siswa dalam kategori cukup. 
Pada siklus III kemampuan aplikasi siswa meningkat secara signifikan, terbukti dengan ketuntasan siswa yang telah mencapai angka 90\% lebih baik 5\% dari siklus II, dengan rincian 18 siswa telah tuntas dalam belajar dengan 2 siswa dalam kategori penialaian amat tinggi dan 11 siswa dalam kategori tinggi dan hanya 2 orang siswa yang belum tuntas.

Tabel 1. Tingkat Ketuntasan Siswa pada Tiap Siklus

\begin{tabular}{cccc}
\hline Tes & Rata- & $\begin{array}{c}\text { Ketuntasan } \\
(\%)\end{array}$ & $\begin{array}{c}\text { Kriteria } \\
\text { Ketuntasan }\end{array}$ \\
\hline Rvaluasi & Rata & 68,42 & Cukup \\
Siklus I & 65,42 & 65 & Baik \\
Siklus II & 70,6 & 85 & Sangat Baik \\
Siklus III & 76,1 & 90 & \\
\hline
\end{tabular}

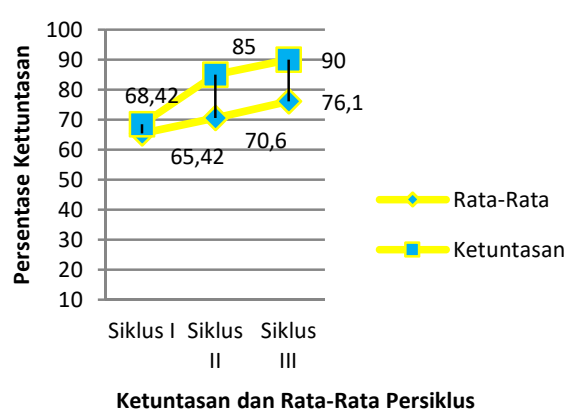

\section{Gambar 3. Peningkatan Rata-Rata dan Ketuntasan Tiap Siklus}

Dari Tabel 1 dan Gambar 3. di atas telah kita ketahui bahwa telah terjadi peningkatan kemampuan siswa pada konsep logika matematika dimana dari siklus 1 , siklus 2, dan siklus 3 kemampuan aplikasi siswa pada subpokok bahasan logika matematika terus meningkat, dari 65,$42 ; 70,6$ hingga menjadi 76,1 dan ketuntasan siswa telah meningkat pula setiap siklusnya, yaitu dari $68,42 \%, 85 \%$, hingga $90 \%$ ini menunjukan kegiatan pembelajaran dengan pendekatan realistik telah dapat meningkatkan kemampuan aplikasi logika matematika siswa dan ketuntasan kelas siswa kelas X.1 SMAN 19 Kab. Bekasi.

Dalam penelitian ini dilakukan post test pada akhir penelitian, pelaksanaan post test dilakukan setelah seluruh siklus pembelajaran berakhir dengan tujuan untuk mengetahui kemampuan aplikasi siswa pada konsep logika matematika setelah mengikuti pembelajaran dengan pendekatan realistik. Rata-rata kemampuan aplikasi matematik siswa pada post test adalah sebesar $77,1 \%$ dengan kriteria penilaian tinggi. Adapun banyaknya siswa yang memiliki kemampuan aplikasi matematik siswa sesuai dengan kriteria penilaian dapat dilihat pada Gambar 4.

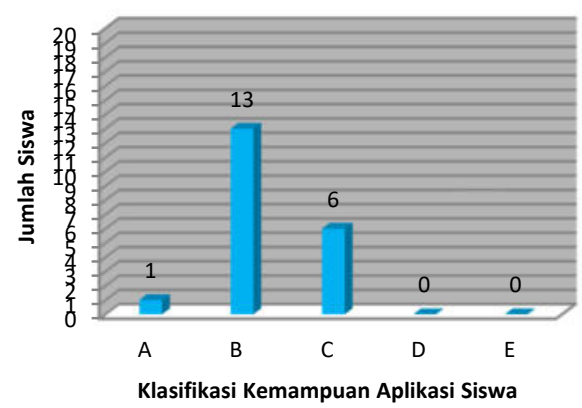

\section{Gambar 4. Klasifikasi Kemampuan Aplikasi Logika Siswa}

Dari hasil analisis data hasil penelitian pada tiap siklus, dapat dilihat bahwa pendekatan realistik terbukti dapan meningkatkan kemampuan siswa dalam ranah aplikasi, hal ini sejalan dengan beberapa penelitian lain dimana penerapan pendekatan realistik terbukti dapat meningkat beberapa aspek dalam hasil belajar siswa. Dalam [8] diperoleh temuan bahwa pendekatan realistik dapat meningkatkan kreativitas siswa dalam pembelajaran kubus dan balok, dan terbukti dapat menyelesaikan permasalahan siswa dalam belajar matematika, selain itu dalam [9] diketahui bahwa hasil belajar matematika siswa dalam ranah kognitif mengalami peningkatan melalui penerapan pendekatan realistik yang dilakukan selama 2 siklus pembelajaran, selain itu ditemukan juga bahwa pendekatan realistik dapat meningkatkan aktivitas siswa dan guru dalam pembelajaran. 


\section{SIMPULAN}

Berdasarkan analisis data penelitian yang diperoleh dilapangan selama menerapkan pendekatan pembelajaran realistik di SMA Negeri 19 Kab.Bekasi kelas X.1 dapat disimpulkan bahwa : aktivitas siswa mengalami peningkatan pada tiap siklusnya. Hal ini dapat dilihat dari persentase rata-rata aktivitas siswa pada setiap siklus, yaitu dari siklus 1 dan 2 masih berkategori cukup, sedangkan untuk siklus 3 aktivitas siswa berkriteria tinggi. Demikian halnya dengan aktivitas guru yang mengalami peningkatan pada setiap siklusnya, pada siklus 1 persentase rata-rata aktivitas guru berkategori cukup, namun pada siklus 2 dan siklus 3 persentase ratarata aktivitas guru berkategori tinggi. Dengan demikian pembelajaran matematika menggunakan pendekatan realistik dapat meningkatkan aktivitas siswa dan guru dalam proses pembelajaran.

Dari hasil tes akhir siklus dapat diketahui rata-rata kemampuan aplikasi siswa, pada siklus 1 berkategori cukup, kemudian pada siklus 2 mengalami peningkatan walaupun masih berkategori cukup dan pada siklus 3 rata-rata kemampuan aplikasi siswa berkategori tinggi. Dari siklus 1 sampai siklus 3 dapat kita simpulkan terjadi peningkatan kemampuan aplikasi siswa. Dengan demikian dapat dikatakan bahwa pembelajaran logika matematika menggunakan pendekatan realistik dapat meningkatkan kemampuan aplikasi siswa walaupun peningkatannya tidak dapat langsung mencapai kriteria yang maksimal.

Hasil tes keseluruhan siklus setelah dilakukan pembelajaran matematika menggunakan pendekatan realistik diketahui bahwa rata-rata kemampuan aplikasi siswa berkategori tinggi.

\section{DAFTAR PUSTAKA}

[1] Erman Suherman, dan Yaya Sukjaya. "Petunjuk Praktis untuk Melaksanakan Evaluasi Pendidikan
Matematika". Bandung: Wijaya Kusuma. 2010

[2] Fahrudin. "Effect of Realistic Mathematics Education (RME) Approach and Initial Ability of Students to the Problem Solving Ability of Class $4^{\text {th }}$ Student. American Journal of Educational Research, Vol.5. no 3 pp. 246-250. 2017

[3] David C.Webb, Henk van der Kooij, and Monica R. Geist. "Design Research in the Netherlands: Introducing Logarithms Using Realistic Mathematics Education". Journal of Mathematics Education at Teachers College Spring-Summer, Vol. 2 no. 6 pp.7-14. 2011.

[4] Tim MKPBM. "Strategi Pembelajaran Matematika Kontemporer". Bandung: JICA .2011.

[5] Peter Airasian, W. dkk. "Kerangka Landasan untuk Pembelajaran, Pengajaran, dan Asesmen (Revisi Taksonomi Bloom)". Yogyakarta: Pustaka Pelajar, 2010.

[6] Asep Jihad. "Evaluasi Pembelajaran". Yogyakarta: Multi Press. 2012.

[7] W. Gulo. "Srategi Belajar Mengajar". Jakarta: Gramedia Widiasarana Indonesia. 2011

[8] M. Anwarul Huda. "Pembelajaran Kubus dan Balok dengan Pendekatan $R M E$ untuk Menumbuhkan Kreativitas Siswa MTs". Jurnal Pendidikan Sains, Volume 1, No.4 pp 390-396. 2013

[9] Nida Jarmita dan Hazami, "Ketuntasan hasil belajar siswa melalui pendekatan realistic mathematics education pada materi perkalian". Jurnal Ilmiah Didakta, Volume XIII. No. 2. Pp. 212-222. 2013 